\title{
Fake news y enseñanza del Portugués: identificación de características y procedimientos de comprobacíón de hechos
}

\author{
Isadora Oliveira do Nascimento \\ isadora.nascimento@ufersa.edu.br \\ https://orcid.org/0000-0002-5690-918X \\ Universidade Federal Rural do Semi-Árido (UFERSA) \\ Caraúbas, Brasil \\ Vicente de Lima-Neto \\ vicente.neto@ufersa.edu.br \\ https://orcid.org/0000-0001-5068-666X \\ Universidade Federal Rural do Semi-Árido (UFERSA) \\ Caraúbas, Brasil
}

Recibido: 31/03/2021 Aceptado: 30/09/2021

\begin{abstract}
Resumen
El tema de las fake news recorre la historia de la humanidad, pero, debido al impulso a través de los sitios de redes sociales y aplicaciones de mensajería, han sido objeto de estudios en diferentes campos del conocimiento, incluso en el área de Educación, donde funcionar. Nuestro objetivo es ayudar a los estudiantes de secundaria en la identificación de noticias falsas a través de un folleto didáctico. Nos avalan Wardle (2017) y D'Ancona (2018), por los conceptos de desinformación y posverdad; además de Tobias (2018) y Seserig y Máximo (2017), por las concepciones de fake news. Metodológicamente, seleccionamos un corpus de dos fake news comprobadas que circularon entre septiembre de 2019 y abril de 2020 en los sitios de redes sociales y lo sometimos a una pantalla analítica utilizando un paquete de categorías que ayudan a definir las fake news de carácter político, teniendo en cuenta el objetivo en la enseñanza de estos contenidos para trabajar en la enseñanza de portugués en la escuela secundaria brasileña. Los resultados llevaron a la creación de un folleto didáctico, dirigido a estudiantes y profesores, que ayuda a verificar la información a la luz de dos categorías: las características de expresión y los contenidos que cruzan las fake news.
\end{abstract}

Palabras-clave: Enseñando.Fake News. Revisión de hechos.

\section{Fake news e ensino de língua portuguesa: identificação de características e procedimentos de checagem de fatos}

\section{Resumo}

A problemática das fake news atravessa a história da humanidade, mas, por conta do impulsionamento via sites de redes sociais e aplicativos de mensagens, elas vêm sendo pauta de estudos em diferentes searas do conhecimento, inclusive na área de Ensino, onde nos inserimos. Nosso objetivo é o de auxiliar alunos de Ensino Médio na identificação das fake news através de uma cartilha didática. Estamos amparados em Wardle (2017) e D'Ancona (2018), para os conceitos de desinformação e de pós-verdade; além de Tobias (2018) e Seserig e Máximo (2017), para as concepções de fake news. Metodologicamente, selecionamos um corpus de duas fake news comprovadamente falsas que circularam entre setembro de 2019 e abril de 2020 em sites de rede sociais e o submetemos a um crivo analítico utilizando um feixe de categorias que ajudam a definir fake news de cunho político, tendo em vista didatizar esses conteúdos para o trabalho em ensino de língua portuguesa no 
Ensino Médio brasileiro. Os resultados levaram à criação de uma cartilha didática, voltada para alunos e professores, que auxilia na checagem de informações à luz de duas categorias: as características de expressão e de conteúdo que atravessam as fake news.

Palavras-Chave: Ensino. Fake News. Checagem de fatos.

\title{
Fake news and Portuguese language teaching: identification of characteristics and procedures for fact checking
}

\begin{abstract}
The issue of fake news runs through the history of humanity, but, due to the boost via social networking sites and apps of messages, they have been the subject of studies in different fields of knowledge, including in the area of Education, where we operate. Our goal is to assist high school students in the identification of fake news through a didactic booklet. We are supported by Wardle (2017) and D'Ancona (2018), for the concepts of disinformation and post-truth; in addition to Tobias (2018) and Seserig and Máximo (2017), for the conceptions of fake news. Methodologically, we selected a corpus of two proven fake news that circulated between September 2019 and April 2020 on social networking sites and submitted it to an analytical screen using a bundle of categories that help to define politic fake news, taking into account aimed at teaching these contents to work in teaching Portuguese Language in Brazilian high school. The results led to the creation of a didactic booklet, aimed at students and teachers, which assists in checking information based in two categories: the characteristics of expression and content that cross fake news.
\end{abstract}

Keywords: Teaching. Fake news. Fact check.

\section{Introdução}

Calígula foi imperador romano de 37 d.C. até 41 d.C., quando foi assassinado por sua guarda pretoriana. Diz a história que era um homem cruel e insano, mas também muito extravagante. Uma de suas histórias mais famosas é a de que o amor e devoção que tinha a seu cavalo Incitatus o levaram a nomear o animal como cônsul, afrontando o Senado. Mesmo dois mil anos depois, a história ainda é tida, na crença popular, como mais uma das insanidades atribuídas a Calígula. $\mathrm{O}$ fato é que isso jamais se confirmou historicamente, uma vez que nenhum autor clássico contemporâneo do imperador tenha se referido a isso. O mais provável é que a história tenha circulado com a finalidade de execração política muitos anos após a morte de Calígula ${ }^{1}$.

Embora o termo fake news tenha se popularizado a partir de 2016, nas eleições presidenciais americanas, elas são práticas muito antigas que podem receber outras nomenclaturas como boatos, fofocas e rumores. Visam influenciar as crenças das pessoas através da apresentação de informações falsas e/ou incompletas, por meio de elementos de

\footnotetext{
${ }^{1}$ Remetemos o leitor a Marqués (2019), caso tenha interesse de se aprofundar em outras fake news oriundas da Antiga Roma.
} 
convencimento, visando criar situações de conflito e influenciar posicionamentos políticos (SANTAELLA, 2018). Também são comuns promessas enganosas feitas por políticos, ao eleitorado e as histórias chocantes (e enganosas) publicadas pela mídia, que atraem o público recorrendo a manchetes chamativas são exemplos desse fenômeno (WARDLE, 2017).

O presente artigo trata-se de um recorte da pesquisa realizada para o trabalho de dissertação junto ao Programa de Pós-Graduação em Ensino (POSENSINO). Inserida num projeto maior do Grupo de Pesquisa GLINET, ela surgiu com o objetivo de auxiliar os alunos de Ensino Médio na identificação das fake news fazendo uso de uma cartilha ${ }^{2}$ didática. Motivada também por habilidades a serem trabalhadas na Base Nacional Comum Curricular - BNCC (BRASIL, 2018) ${ }^{3}$, esta pesquisa também busca preencher essa lacuna, para a qual nos centramos na análise de fake news políticas veiculadas em plataformas digitais, com a identificação das características encontradas neste tipo de notícias falsas e a posterior sistematização dos achados no produto educacional. As fake news analisadas giravam em torno da agressão por arma branca, promovida por Adélio Bispo de Oliveira, no ano de 2018, contra o então candidato à presidência Jair Bolsonaro e a posterior multiplicação de fake news em torno dessa nova figura pública às vésperas da eleição presidencial de 2018.

O estudo é de manifesta importância em razão da emergente necessidade de se facilitar o reconhecimento das fake news e, assim, minorar o efeito danoso que essa manifestação causa para a sociedade. Neste artigo, objetivamos sistematizar características que podem ser localizadas em fake news políticas através da materialidade textual e contextual. Para este artigo, analisaremos um corpus composto por duas fake news captadas nas plataformas digitais Twitter e Facebook.

\section{A era da Pós-verdade, fake news, bolhas-filtradas}

O conceito de Pós-verdade, conforme o Dicionário de Oxford, significa circunstâncias em que os fatos objetivos possuem menor poder de influenciar a formação da opinião pública do que apelos às emoções e às crenças pessoais. Há, entre Fake News e PósVerdade, uma relação muito próxima. Coelho (2018) aponta que aquilo que é criado dentro da Pós-Verdade tem por intuito servir aos interesses de alguém.

\footnotetext{
${ }^{2}$ Embora resgate um termo tradicional, entendemos a cartilha aqui como uma espécie de manual didático, que ajuda a explicar determinados fenômenos em diferentes áreas do conhecimento, ora como um tutorial, ensinando o leitor; ora detalhando fenômenos.

${ }^{3}$ Cf. Habilidades EM13LP39 e EM13LP40 da BNCC (BRASIL, 2018, p.511-512)
} 
Rodrigues (2018) afirma que as fake news são subprodutos da Pós-verdade, e que, diante dessa problemática, a postura mais eficaz a se assumir é a quebra da dicotomia verdade-mentira e a efetiva compreensão dos efeitos produzidos, uma vez que a própria sociedade gera diversas reações, como as mencionadas fake news e os haters - termo utilizado para fazer referência àquelas pessoas com comentários de ódio ou críticas sem critério, e não apenas mentiras - ambas subprodutos da 'Pós-verdade'.

D`Ancona (2018, p. 10) afirma, quanto à relação pós-verdade e mentiras:

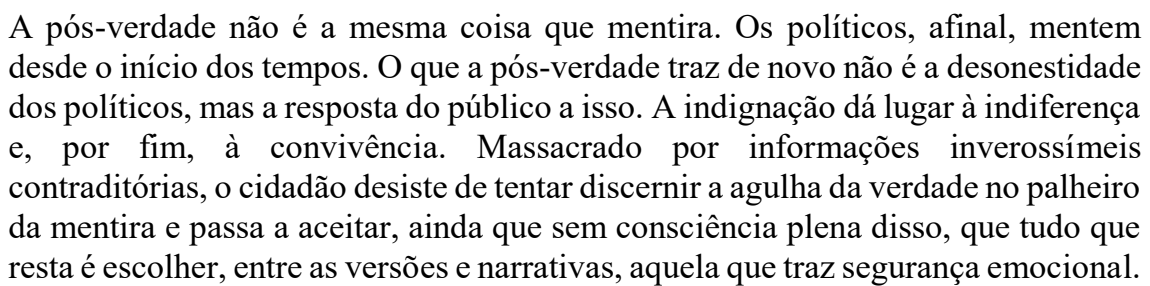

Assim, as fake news têm uma relação muito particular com a pós-verdade, por serem conteúdos que buscam evocar sentimentos e, com frequência, fabricam uma revolta com relação à entidade ou pessoa que está sendo deslegitimada (PAULA; SILVA; BLANCO, 2018).

Conforme Angelis (2017), nas comunidades nas quais a pós-verdade está inserida, existe uma maior tendência de manipulação dos sujeitos pelas fake news. Tal efeito se dá em razão do fator psicológico denominado "viés da confirmação", o qual trata da disposição humana de crer nas informações que mais se aproximam de suas próprias crenças e opiniões, rejeitando as opções contrárias, sendo, pois, atraídos pelo falso senso de credibilidade existente nas plataformas digitais. Isso significa que acreditar ou não em fake news não tem a ver com grau de instrução, mas sim com suas próprias crenças e emoções.

De acordo com Wardle (2017), a "seleção expositiva", ou seja, o uso, pelos buscadores, de fontes que compartilhem das mesmas opiniões que o usuário, acaba ocasionando um aumento da polarização, uma vez que as opiniões emitidas são validadas sem que haja um necessário debate sobre elas, formando, assim, espaços seguros, nos quais são compartilhadas crenças e visões de mundo, com outras pessoas, sem confrontação de ideias. Tais espaços virtuais são as bolhas-filtradas.

As bolhas filtradas, segundo Pariser (2012), ocasionam o fechamento frente às novas ideias, assuntos e informações relevantes - através da personalização dos filtros promovida por algoritmos. Os filtros funcionam como formas de manipulação que posicionam o usuário, carente de informações corretas, a serviço de interesses diversos. Tal fato gera um 
prejuízo não somente na seara particular, mas também reverbera na seara coletiva por reafirmar, inclusive, interesses políticos escusos.

Figura 1 - Esquema de funcionamento das bolhas-filtradas

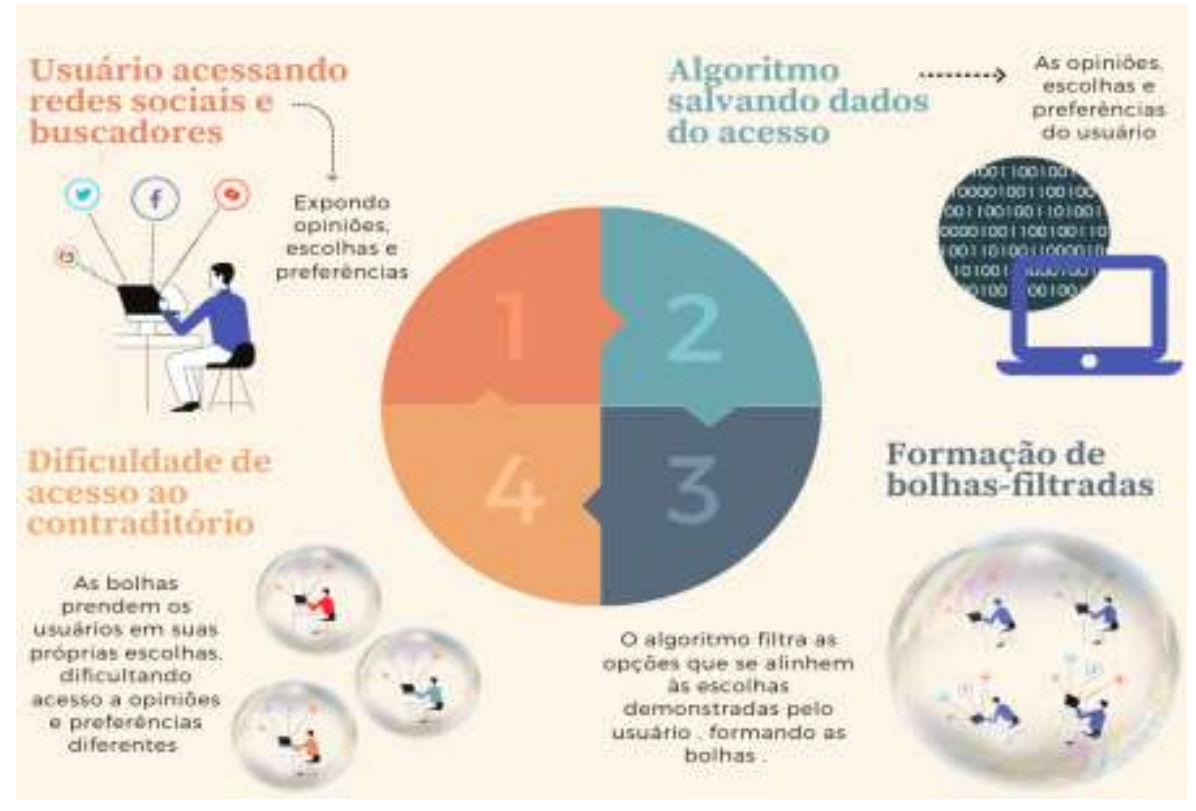

Fonte: Nascimento (2020)

No momento 1, o usuário, ao utilizar suas plataformas digitais e mecanismos de busca, efetua escolhas, deixando, na internet, vestígios de opiniões e preferências. Tais dados são coletados por algoritmos (momento 2) e, a partir de então, passam a oferecer ao usuário as opções que mais se alinhem com o histórico de decisões tomadas pelo usuário (momento 3), desde produtos, até sugestões de amizades com pessoas cujas opiniões se alinhem aos padrões reconhecidos e captados pelo algoritmo, fechando o usuário em bolhas que funcionam como espelhos de suas próprias opiniões e preferências, privando-o ou dificultando o acesso ao contraditório (momento 4), por não oferecer, de forma facilitada, o contato a outras opiniões, preferências e escolhas feitas por outras pessoas na internet.

A mente humana funciona com base em reconhecimento de padrões, de forma que se atrai por padrões já reconhecidos, em detrimento dos desconhecidos. Em razão disso, emprega-se menor esforço e energia mentais diante de situações e informações já conhecidas, do que diante de novos fatos que obriguem o sujeito a nutrir novos hábitos de pensamento. A mudança de hábitos de pensamento implica, diretamente, mudanças de ação, o que explica o fato de os sujeitos evitarem digerir novas informações, sobretudo aquelas contrárias ao pensamento até então mantido, pois, do contrário, implicaria um grande esforço 
em pensar, sentir e, por consequência, agir diferente (PEIRCE, 1958 apud SANTAELLA, 2018).

As opiniões e crenças formadas pelas pessoas se dão por fatores complexos, de modo que é imprescindível que se formem cidadãos dotados de habilidades cognitivas capazes de analisar conteúdos e contextos (SANTAELLA, 2018). Auxiliar pessoas no desenvolvimento de uma formação crítica para as mídias deve ser a primeira defesa contra todas as "doenças digitais" (CHAPMAN, 2017). Com efeito, defendemos que a análise crítica - apresentada na Pedagogia dos Multiletramentos (COPE; KALANTZIS, 2015) - aliada à educação para as mídias busca ajudar na formação de educandos com senso crítico suficiente para lidar com os problemas decorrentes do excesso informacional propalado na mídia.

Conforme Chapman (2017), a suposição de uma década atrás era de que as crianças deveriam permanecer isoladas da internet, como forma de protegê-las. Porém, nos dias atuais, diante de uma situação social completamente diferente daquela apresentada em outrora, às crianças deve ser dada a oportunidade de tornarem-se resilientes, empoderadas com as habilidades, conhecimento e suporte necessários ao uso da internet e mídias sociais de forma segura. Essa é a tarefa da educação para e nas redes, exigindo aprendizado e envolvimento contínuo para o acompanhamento das problemáticas que forem surgindo.

Não é à toa que esse discurso resvala na BNCC (BRASIL, 2018), que, no que tange ao ensino da área de linguagens e suas tecnologias no Ensino Médio, dedica a sétima competência ao trabalho com tecnologias digitais:

Mobilizar práticas de linguagem no universo digital, considerando as dimensões técnicas, críticas, criativas, éticas e estéticas, para expandir as formas de produzir sentidos, de engajar-se em práticas autorais e coletivas, e de aprender a aprender nos campos da ciência, cultura, trabalho, informação e vida pessoal e coletiva.

O que se vê é que documentos norteadores da educação nacional agora já se debruçam sobre as produções de sentido em ambiência digital, indo para além dos usos das técnicas das tecnologias digitais de informação e comunicação. Exige-se uma perspectiva crítica do alunado, de maneira que eles agora consigam não apenas usar as interfaces, mas triar e curar informações, preocupações essas que não existiam em documentos anteriores.

Conhecer fontes confiáveis é o início da educação midiática (BOYD, 2017). Encorajar os estudantes a buscar as fontes de informação de excelência traduz-se em impulsioná-los a pesquisar criticamente o autor do conteúdo publicado, se é fonte segura e busca imparcialidade. Logo, é necessário tornar as pessoas capazes de captar as diferentes 
perspectivas e buscar sentido naquilo que lhe é repassado através da tecnologia da informação. Para tanto, os padrões educacionais tradicionais devem ser abandonados, uma vez que todo o contexto social vem passando por grandes alterações. No tópico a seguir, discorreremos mais detidamente acerca das fake news e a desordem da informação.

\subsection{Fake News, Misinformation e Desinformation}

A maior parte das discussões relacionadas às fake news convergem para três aspectos principais: informações erradas, informações intencionalmente falsas e informações verdadeiras divulgadas com a intenção única de prejudicar terceiros. Nesse sentido, a terminologia fake news se torna reducionista para descrever o complexo fenômeno relacionado à produção, difusão e consumo de uma variedade de informações que, dado seu resultado negativo, são enquadrados na metáfora "poluição" informacional. (WARDLE, 2017, p. 5).

Tal caráter reducionista do termo impede a necessária diferenciação de um compartilhamento feito sem um juízo de ponderação (a exemplo de uma pessoa que não possui letramento digital suficiente para uma pesquisa externa) de um conteúdo criado e difundido com finalidades escusas. Ademais, a maior parte das situações é erroneamente classificada como "notícia", quando, na verdade, correspondem aos rumores à moda antiga, memes, vídeos manipulados, fotos antigas resgatadas e compartilhadas como se fossem novidade (WARDLE, 2017, p. 5). Por essas razões, nesta pesquisa, utilizaremos a concepção mais ampla do fenômeno, defendida por Wardle (2017) através do Quadro da Desinformação, porém recorreremos à nomenclatura "Fake News" por ser a mais socialmente utilizada.

Wardle (2017) introduz uma nova estrutura conceitual para examinar o que ela intitula de Desordem da Informação. Tal quadro é composto por três tipos diferentes de desordem (Mis-information, Des-information e Mal-information). A mis-information é caracterizada por informações erradas, mas sem ter a intenção de causar prejuízo a outrem. Compartilhar uma informação falsa sem consultar a fonte, na tentativa de ajudar outros, é um exemplo de mis-information.

A Dis-information (desinformação, em tradução livre) é caracterizada pelas informações falsas que são compartilhadas conscientemente, visando causar danos diversos. A Dis-information pode ocorrer, por exemplo, através da fabricação ou manipulação 
deliberada de conteúdo imagético ou visual, criação intencional de teorias da conspiração e rumores (WARDLE, 2017).

A Mal-information (má informação, em tradução livre) se dá com o compartilhamento público de informações verdadeiras, porém, de caráter privado, visando prejudicar uma pessoa ou sua reputação, a exemplo do pornô de vingança. (WARDLE, 2017).

Considerando as dimensões da falsidade e da prejudicialidade, a intersecção formada pelas dimensões Dis-information e a Mal-information resulta naquilo que mais se aproxima da forma como entendemos as fake news políticas: informações falsas, postadas intencionalmente, com o fito de prejudicar outrem. Por tal razão, adotaremos o posicionamento de Nascimento (2020) no sentido de nos determos a apresentar as categorias Dis-information e Mal-information.

Ao realizar a divisão do quadro da desinformação em três categorias, Wardle (2017) realizou, ainda, a apresentação de características constantes em cada uma das dimensões e que são sobremaneira úteis na identificação das fake news políticas, conforme figura abaixo:

Figura 2 - Desordem da Informação

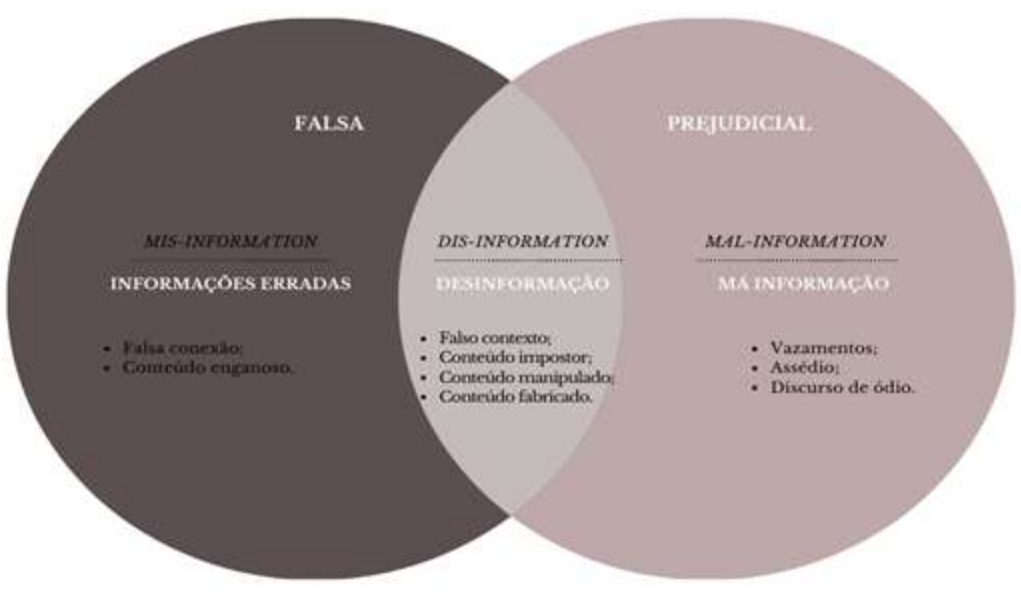

Fonte: Nascimento (2020, adaptado de WARDLE, 2017)

Conforme Nascimento (2020), a falsa conexão se dá quando os títulos, as legendas, as fotos, ilustrações e/ou as legendas não se relacionam com o conteúdo verbo-textual ou recurso a que se vinculam. Assim, em uma leitura distraída, o leitor pode ser manipulado a concluir algo que não é afirmado através do conteúdo completo. Tal característica pode ser identificada através da materialidade textual, caso o leitor reconheça que a conexão estabelecida não é verdadeira, ou que realize uma checagem dos fatos. 
O conteúdo enganoso ocorre com disseminação de informações falsas ou, ainda, de informações verdadeiras manipuladas de modo a levar a uma conclusão inadequada sobre uma pessoa ou assunto, podendo, inclusive, caracterizar calúnia, injúria ou difamação por serem reportados falsamente, a terceiros, a prática de crimes ou de situações que possam lesionar a imagem/reputação/honra.

O falso contexto é caracterizado pela disseminação de um conteúdo verdadeiro (fotografia, fato social, personagens) que foi isolado de seu contexto original de produção e empregado em contexto diverso, com a intenção de manipular o leitor a acreditar no contexto falsamente criado. A identificação dessa característica poderá ocorrer através da materialidade textual, caso o leitor reconheça os fatos e pessoas e o contexto de aplicação; do contrário, uma busca dos fatos e pessoas envolvidas se faz necessário para a identificação (NASCIMENTO, 2020, p 64.).

O conteúdo impostor ocorre com a citação de falsas falas que são atribuídas a determinadas fontes (de renome ou apelo social) para gerar credibilidade. Tal característica é identificável através da checagem dos dados, enquanto o conteúdo manipulado se realiza com a manipulação de informações verdadeiras tendo por intuito enganar o leitor. Pode ocorrer através de manipulação imagética (montagens, por exemplo) ou verbal (recortes e inserções de fatos falsos). Tais manipulações podem ser verificadas através da observação, sobretudo nas hipóteses de montagens imagéticas muito grosseiras, ou através de uma análise refinada dos fatos, como uma pesquisa externa à materialidade textual.

O conteúdo fabricado, por sua vez, é caracterizado pela criação de uma informação totalmente falsa, criada unicamente para enganar. Em uma leitura rápida, lança o tom de novidade. A forma de identificar a falsidade informacional também se dá através da análise e busca dos pontos apresentados.

Outras searas do conhecimento também contribuem para os trabalhos com fake news e devem ser chamadas à discussão. Tobias (2018), por exemplo, parte da Ciência da Informação para empreender suas análises, cujas categorias de prestígio endossado por terceiro e sensacionalismo foram reveladas, as quais servem aos nossos propósitos. $\mathrm{O}$ prestígio endossado por terceiro é a característica que se dá com o enaltecimento ou depreciação de uma pessoa, instituição ou marca. Tal aspecto está relacionado à parcialidade da informação. Quanto ao sensacionalismo, conforme Tobias (2018), se dá com o emprego do exagero e apelo emocional, recorrendo para as sensações do leitor.

Da pesquisa empreendida por Seserig e Máximo (2017), oriunda da Comunicação Social, duas categorias são extraídas: a falta de apuração e as teorias da conspiração. 
Conforme Seserig e Máximo (2017), a falta de apuração é uma categoria que analisa casos em que um ou mais sujeitos do acontecimento acabam sendo beneficiados pela negligência (deliberada ou não) ou desconhecimento dos profissionais que apuram e veiculam fatos. Em Nascimento (2020), pensou-se esta categoria sob a perspectiva inversa: a falta de apuração/entendimento como gerador de prejuízos diversos às partes envolvidas, atendendo interesses externos escusos. As teorias da conspiração se configuram como sendo histórias que atacam ideias já estabelecidas, gerando falsas controvérsias, ou fantasiam fatos muito comentados em um dado contexto.

Todas essas categorias foram agrupadas em duas maiores, que chamamos de a) critérios de expressão e b) critérios de conteúdo. A primeira categoria se caracteriza por serem flagrados na materialidade textual, de mais fácil detecção: conteúdo manipulado, falso contexto, sensacionalismo, falta de apuração, erros gramaticais. A segunda mostra aqueles traços que necessitam uma análise mais aprofundada, indo além da materialidade semiótica e partindo para procedimentos de checagem em outras fontes. Estão aqui a falsa conexão, os conteúdos enganoso, impostor e fabricado, além do prestígio endossado por terceiros e as teorias de conspiração ${ }^{4}$. Essa abordagem teórica foi submetida ao crivo analítico de um corpus, descrito numa metodologia de trabalho sobre a qual nos debruçamos a seguir.

\section{Dos procedimentos metodológicos}

A pesquisa se enquadra na perspectiva da abordagem qualitativa, o que se dá pelo fato de não haver pretensão de se trabalhar com exatidão de variáveis. Conforme Richardson (2017), o pesquisador que se utiliza de abordagens qualitativas enxerga os fenômenos sociais sob uma perspectiva mais holística, o que corrobora o fato de as pesquisas qualitativas apresentarem visões mais amplas, empregando raciocínios multifacetados e interativos (RICHARDSON, 2017, p. 68).

Quanto à natureza, a pesquisa caracteriza-se descritiva-exploratória. Conforme Gil (2008), tal pesquisa objetiva descrever as características de determinada população ou fenômeno, ou mesmo o estabelecimento de relações entre variáveis. Uma de suas características é a coleta de dados e observação sistemática. Nossa pesquisa, por meio da

\footnotetext{
4 Reconhecemos que expressão e conteúdo não são estanques; trata-se de uma forma mais didática de apresentar determinadas categorias que podem ser mais facilmente flagradas no plano da materialidade semiótica, mas não impedem que categorias que assumimos estarem nos critérios de expressão não estejam nos de conteúdo.
} 
coleta, observação e análise do corpus, busca as características constantes nas fake news do viés político que são disseminadas em diferentes plataformas digitais.

Trazemos aqui arranjos de cunho netnográfico (HINE, 2005): embora não tenhamos sido diretamente inseridos ou aceitos por um grupo ou comunidades específicas a que pudéssemos observar e delas participar, o que caracterizaria a netnografia (HINE, 2005), mas atuamos na condição de usuários das plataformas digitais, locais onde o fenômeno das fake news ocorre com muito mais eficácia. A pesquisa se deu em ambiente virtual, mais especificamente nos sites Aos fatos e Boatos.org e nas plataformas digitais Facebook e Twitter.

Relacionando as agências de busca às plataformas digitais, buscamos a checagem de informações ligadas à figura de Adélio Bispo de Oliveira e, por consequência, dos boatos gerados em torno da situação protagonizada por ele quando do atentado ao, à época, presidenciável Jair Bolsonaro e já checados como comprovadamente falsos.

Dotados do conhecimento acerca de determinado boato, buscamos a manifestação dele nos sites de rede social Facebook e Twitter, com a intenção de flagrá-los no ambiente em que surgiram ou que foram disseminadas as Fake News, para, a partir daí, constituir nosso corpus de pesquisa. Utilizamos palavras chaves do boato, como "Adélio Bispo Lula" nos mecanismos de busca das plataformas digitais e, havendo resultado, coletamos seis boatos postados entre setembro de 2019 e abril de 2020 para análise e consequente constituição de nosso corpus $^{5}$. Para este artigo, selecionamos dois deles, um veiculado no Twitter e outro no Facebook, cuja análise se dará na subseção subsequente.

\section{Das características das fake news políticas}

A primeira Fake News analisada foi postada no Twitter, no ano de 2020, mas diz respeito a um boato que circula desde o ano de 2018 e sustenta a tese da participação de uma mulher, Aryane Campos, na agressão praticada por Adélio Bispo contra Jair Bolsonaro.

\footnotetext{
${ }^{5}$ No ano de 2018, o então presidenciável Jair Messias Bolsonaro foi atingido por um golpe de arma branca, durante um comício, em Minas Gerais, por Adélio Bispo de Oliveira. A partir de então, surgiram muitas fake news associadas a Adélio Bispo, inclusive, atrelando esta nova figura midiática a outras figuras políticas como Lula, PT, PSOL, dentre outros. Na pesquisa da qual este artigo se originou, o corpus foi constituído por seis boatos, publicados em diferentes meios, como Facebook, Twitter, Youtube, além do repasse de alguns deles por whatsapp, entre o período de setembro de 2018 a abril de 2020.
} 
Figura 3 - Fake news postada no Twitter

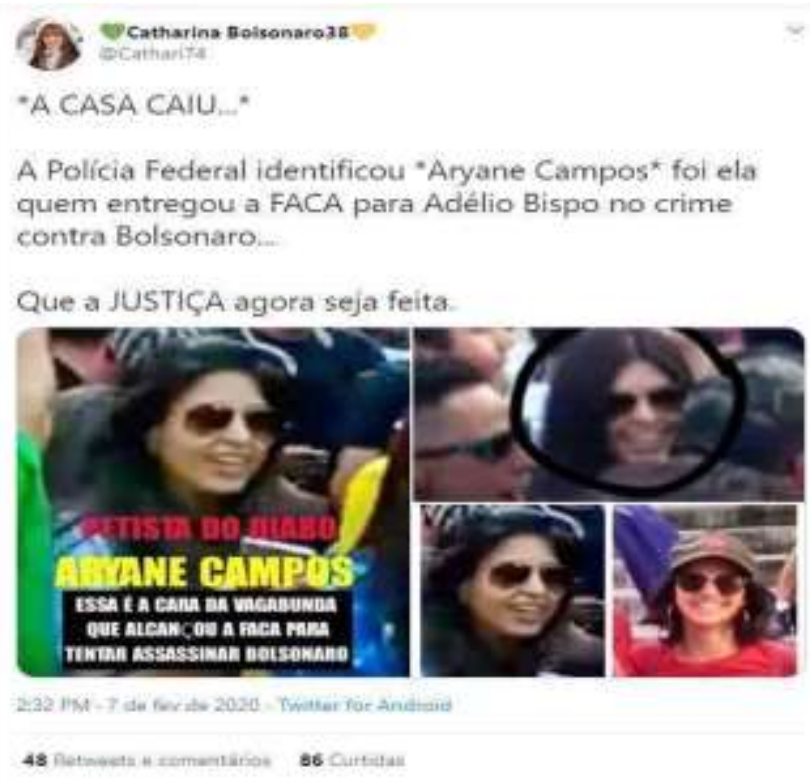

Fonte: (A POLÍCIA..., 2020)

A postagem, iniciada com os dizeres "A CASA CAIU" demonstra o caráter sensacionalista da informação, apelando para a sensação de que algo, finalmente, foi descoberto. Ademais, os dizeres, em letras vermelhas, contrastando com o fundo, onde lemos "Petista do diabo" e, abaixo (também evidenciando o contraste entre a cor das letras e do quadro em que as palavras foram inseridas) "Essa é a cara da vagabunda que alcançou a faca para tentar assassinar Bolsonaro", igualmente evidenciam o sensacionalismo da postagem, bem como o prestígio endossado por terceiros, que é percebido desde o nome adotado pelo perfil (Catharina Bolsonaro), bem como por proferir palavras negativas tanto com relação à garota, quanto por, nas entrelinhas, contra o Partido dos Trabalhadores.

A categoria prestígio endossado por terceiros é identificável através de critérios de expressão e de conteúdo, concomitantemente, uma vez que podem ser visualizados indícios de sensacionalismo por meio do uso de palavras em caixa alta, cores chamativas etc. (critério de expressão). $\mathrm{O}$ ar de novidade que paira sobre a postagem, no entanto, só pode ser refutado recorrendo a uma pesquisa mais apurada (critério de conteúdo). Igual raciocínio se emprega à categoria prestígio endossado por terceiros, uma vez que alguns elementos visualmente expressos indicam a existência da parcialidade, como o nome utilizado pelo perfil e o trecho "Petista do diabo", o que denota o critério de expressão. Entretanto, as falas se pautam em um fato que requer pesquisa externa para se confirmarem 
(o envolvimento de Aryane Campos na agressão, por exemplo), de modo que a categoria se apresenta, também, como critério de conteúdo.

O conteúdo impostor é apresentado com a afirmação de que a Polícia Federal identificou Aryane Campos como sendo a pessoa responsável por auxiliar Adélio Bispo no atentado contra Bolsonaro. Na realidade, a Polícia Federal descartou a participação de uma mulher (SERAPIÃO, 2018) e concluiu inquérito apontando que Adélio agiu sozinho (PF, 2018), não havendo um mandante do crime. A categoria conteúdo impostor, por apresentar afirmação atribuída à Polícia Federal, se enquadra nos critérios de conteúdo, uma vez que requer pesquisa mais aprofundada que permita refutar ou confirmar o que foi dito na postagem.

Assim, é possível identificar a falta de apuração, tanto pelo fato de já haver sido concluído o inquérito que aponta que Adélio agiu sozinho e tal conclusão ser pública, quanto por não haver, na publicação, a indicação de novos fatos que ensejassem, por exemplo, a reabertura do inquérito em razão do surgimento de novas provas acerca do crime. Dessa forma, percebemos a intenção única da postagem como sendo de enganar o leitor, logo, um conteúdo fabricado.

A falta de apuração pode ser identificada através de critérios de expressão, uma vez que não há menção a qualquer fonte. Ademais, com uma pesquisa externa ao texto, os fatos apresentados não são confirmados, o que permite, também, a identificação da categoria através dos critérios de conteúdo.

Ademais, a falsa conexão resta evidenciada pela associação das imagens, que são postas como se ambas dissessem respeito à mesma pessoa, quando, na verdade, uma delas foi retirada do comício em que ocorreu o crime e retrata uma moça que se encontrava no local, no meio da multidão. Na outra foto, aparece Aryane, cuja foto foi capturada de suas redes sociais. Uma simples comparação já torna possível perceber que são pessoas diferentes, fato corroborado pelo inquérito policial que concluiu não haver qualquer participação dela.

A falsa conexão pode ser identificada, no caso, através dos critérios de expressão e conteúdo. Através da expressão, a categoria se manifesta visualmente, através de uma simples leitura que permita ao leitor perceber que as fotografias apresentam pessoas diferentes e que, portanto, o texto da postagem não condiz com as imagens. No entanto, caso tal diferença das fotografias não seja visível ao leitor, há a necessidade de uma checagem que confirme a falsa conexão estabelecida pela postagem, portanto, através de critérios de conteúdo. 
É possível perceber, também, a formação de teorias da conspiração segundo as quais Adélio Bispo agiu a mando de alguém e que há relação entre a agressão e o PT. Tais teorias da conspiração, para serem refutadas efetivamente, necessitam de uma checagem dos fatos apresentados, o que torna a categoria identificável através de critérios de conteúdo. Como se vê, esse boato, já checado e comprovadamente falso, pode se manifestar de diferentes maneiras e congregar diferentes seguidores em sites de redes sociais, que acreditam na questão, retuítam e comentam a postagem, aumentando o engajamento e espalhando inverdades. No Facebook, os mecanismos de engajamento se assemelham, como a seguinte.

A postagem aponta que Lula e Adélio Bispo são representados pelo mesmo advogado e, para embasar a fala, é realizado o comparativo entre imagens onde há uma suposta prova de que se trata da mesma pessoa.

Figura 4 - Fake News postada no Facebook

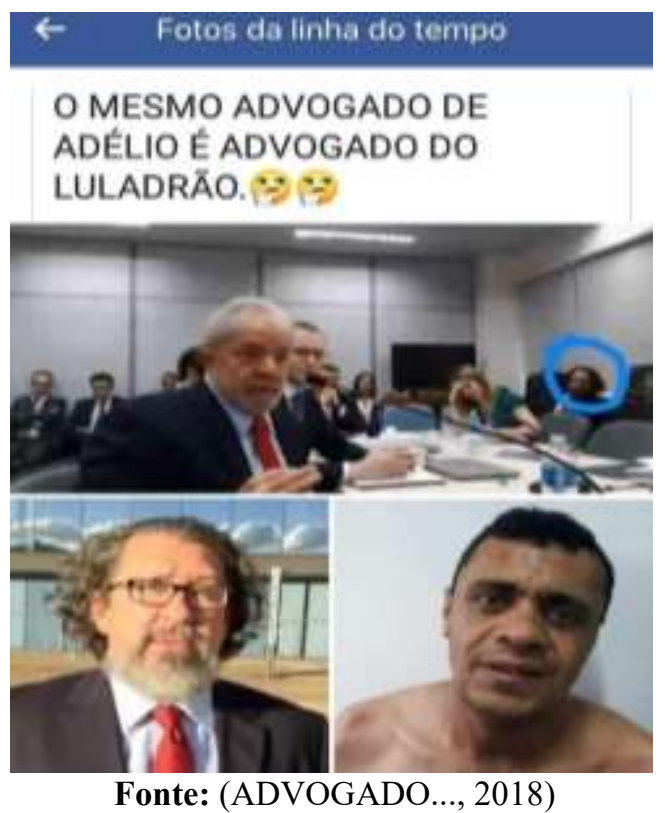

O autor da postagem intentou relacionar as figuras de Lula e Adélio Bispo através de uma suposta defesa ser efetuada pelo mesmo advogado. O sensacionalismo se expressa, na postagem, por meio da escrita em letras maiúsculas "O MESMO ADVOGADO DE ADÉLIO É ADVOGADO DO LULADRÃO”. Outro ponto é o uso do emoji $i^{6}$, associado à frase, representando uma reflexão, pensamento ou conclusão, de modo que, unidos os

\footnotetext{
${ }^{6}$ Emojis são representações gráficas (desenhos próprios e inéditos) que simbolizam as emoções, tratados como extensões do conjunto de caracteres ocidentais usados na maioria dos sistemas operacionais da atualidade (SOUZA, 2019).
} 
pontos, há um apelo para as sensações do leitor. Por estar na materialidade do texto, o sensacionalismo, nessa postagem, se manifesta através do critério de expressão.

A falsa conexão é estabelecida na postagem com o uso de imagens que não condizem ou comprovam o que é dito na chamada. Na primeira imagem, é apresentado um frame ${ }^{7}$ de um vídeo realizado em uma audiência designada para o depoimento do ex-presidente Lula acerca ao Sítio de Atibaia ${ }^{8}$. Vemos na imagem (de baixa resolução) uma figura masculina com cabelos na altura dos ombros. O texto da fake news vincula essa figura ao advogado de Adélio Bispo, que seria o homem apresentado na figura localizada no canto inferior esquerdo. Adélio, inicialmente, foi defendido por quatro advogados (DAL MOLIN, 2018), sendo o principal deles Zanone Oliveira ${ }^{9}$. Lula, por sua vez, tinha por patronos os advogados do escritório de advocacia Teixeira \& Martins, sendo os principais, Cristiano Zanin Martins e Valeska Teixeira Zanin Martins ${ }^{10}$, portanto, pessoas diferentes. A falsa conexão, na postagem acima, pode ser identificada por meio dos critérios de expressão e de conteúdo, concomitantemente, uma vez que, caso o leitor reconhecesse, por meio das imagens ou de seu conhecimento de mundo, que os advogados se tratam de pessoas diferentes, tal identificação se daria através dos elementos de expressão. Entretanto, caso seja necessária a busca externa ao texto para a identificação de que são sujeitos diferentes, a identificação se enquadraria nos critérios de conteúdo.

O conteúdo enganoso resta configurado com a apresentação de fatos verdadeiros (Adélio Bispo era representado por um advogado; Lula era representado por um advogado) para levar o leitor a chegar a uma conclusão inadequada de que seriam esses advogados a mesma pessoa. Ademais, a nomenclatura utilizada para nomear Lula ("Luladrão") aponta para uma suposta prática criminosa de roubo, fato que não é comprovado na publicação, mas leva a uma visão negativa da personalidade. Aliar Lula e Adélio Bispo também pode levar o leitor a ter uma percepção incorreta acerca de uma possível proximidade entre eles. A identificação do conteúdo enganoso, na portagem, se dá por meio dos critérios de conteúdo,

\footnotetext{
${ }^{7}$ Frames correspondem às imagens fixas que formam um produto audiovisual (MACHADO, 2011).

${ }^{8}$ Disponível em: https://www.youtube.com/watch?v=MO3bKKEm1b0 Acesso em: 26 mar. 2021.

${ }^{9}$ Disponível em: https://noticias.uol.com.br/colunas/constanca-

rezende/2019/11/01/advogado-de-adelio-bispo-deixa-o-caso-dificil-e-oneroso-diz.htm. Acesso em: 26 abr. 2020.

${ }^{10}$ Disponível em: https://lula.com.br/nota-dos-advogados-do-ex-presidente-lula/. Acesso em: 26 abr. 2020.
} 
uma vez que, apenas através da materialidade textual, talvez não fosse possível compreender e desmentir a relação criada entre os sujeitos.

A nomenclatura "Luladrão" também denota o prestígio endossado por terceiros o que, por si, já demonstra, no mínimo, uma antipatia do criador da publicação pelo expresidente Lula, além de sugerir o posicionamento político do enunciador. Isso reforça as câmaras de eco, as quais são espaços seguros para compartilhamento de crenças e visões de mundo, sem necessariamente debater sobre elas. Tal categoria pode ser identificada através da expressão, uma vez que há, na materialidade textual, indícios de parcialidade na nomenclatura "Luladrão".

A teoria da conspiração e o conteúdo fabricado se apresentam de modo conjunto, uma vez que é criada uma teoria em que Lula e Adélio Bispo são defendidos pelos mesmos advogados, o que leva a crer em uma relação entre eles, o que, nas entrelinhas, poderia ser visto como um conluio contra Bolsonaro, haja vista a agressão praticada por Adélio Bispo contra Bolsonaro e o fato de Lula ser adversário político de Bolsonaro (BRANDINO, 2018). Com efeito, toda essa complexa junção de pontos, que geram a teoria, tem o único intuito de enganar o leitor, o que configura o conteúdo fabricado. Tal complexidade só permite uma compreensão mais efetiva através de uma busca para além do texto, o que nos faz enquadrar tais categorias, nessa publicação, como identificáveis através de critérios de conteúdo.

Muito embora a publicação exponha fatos, sugerindo que são verdadeiros, não há qualquer indicação de onde a informação foi retirada, o que denuncia a falta de apuração. Por ser visível que não há fontes que confirmem o que está sendo dito, tal categoria é identificável, na postagem, através do critério de expressão.

\subsection{Identificando Fake News: cartilha didática para alunos do Ensino Médio}

Tomando as análises vistas anteriormente, pensou-se em didatizar essas estratégias para alunos e professores do Ensino Médio, considerando as perspectivas abordadas pela BNCC (BRASIL, 2018) e por habilidades voltadas para checagem de fatos e trabalhos com curadoria de informações. Nascimento (2020) sugere, numa cartilha, como as categorias de expressão e conteúdo se caracterizam: 
Figura 5 - Sugestão de trabalho com critérios de expressão e conteúdo na cartilha

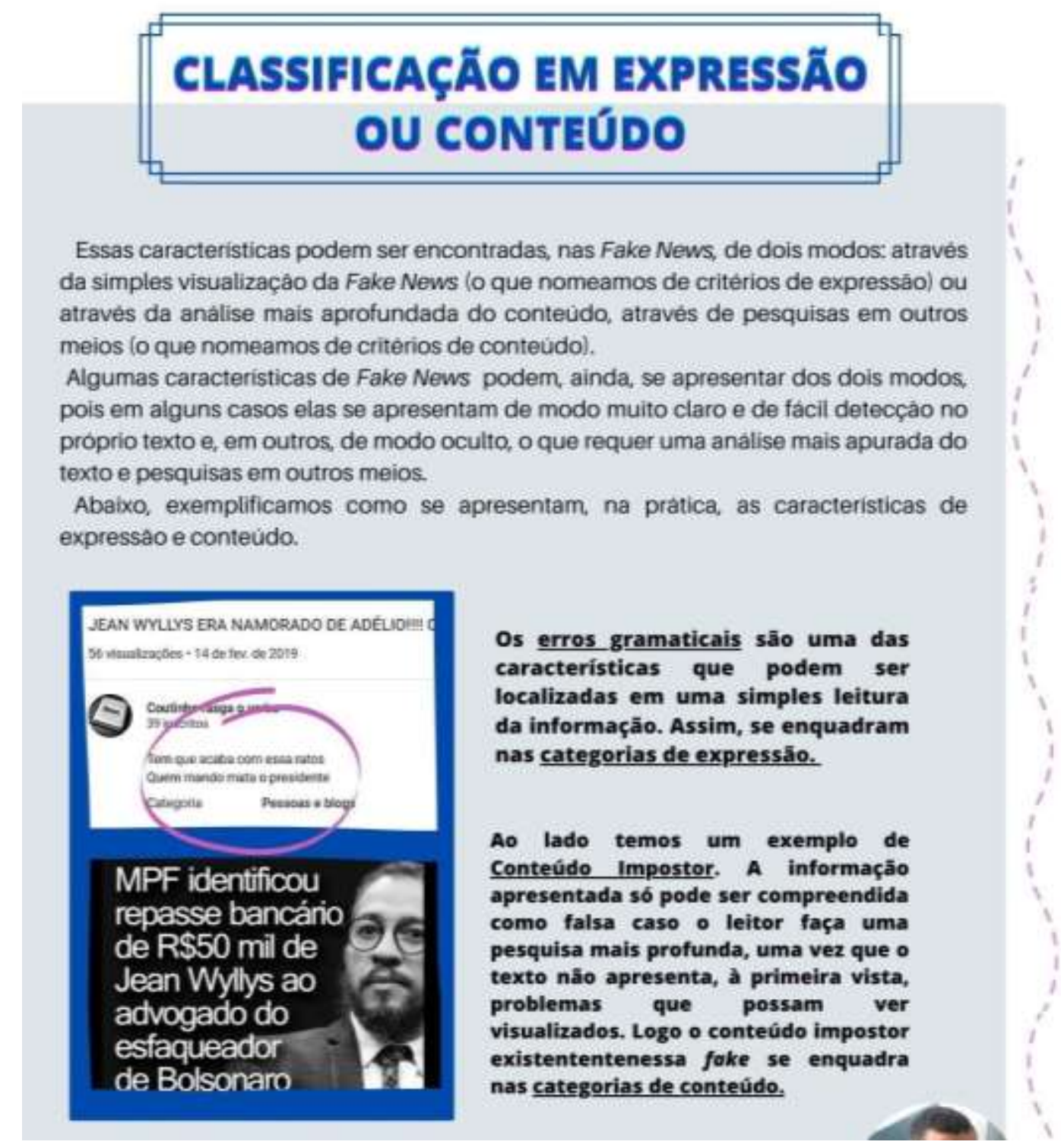

Fonte: Nascimento (2020)

Como se vê, a estratégia foi a de evitar um linguajar acadêmico, pensando no públicoalvo da educação básica. Não abrimos mão das nomenclaturas técnicas, embora tentemos didatizá-las com exemplos que são palpáveis para quaisquer públicos. Além disso, pensamos num layout mais atrativo, com misturas de cores, imagens e elementos multimodais de saliência, para mostrar detidamente o que queremos, pensando em tornar a cartilha um produto acessível ao público-alvo. A seguir, também resumimos as categorias de análise da pesquisa na cartilha: 
Figura 6 - Resumo das categorias de análise na cartilha

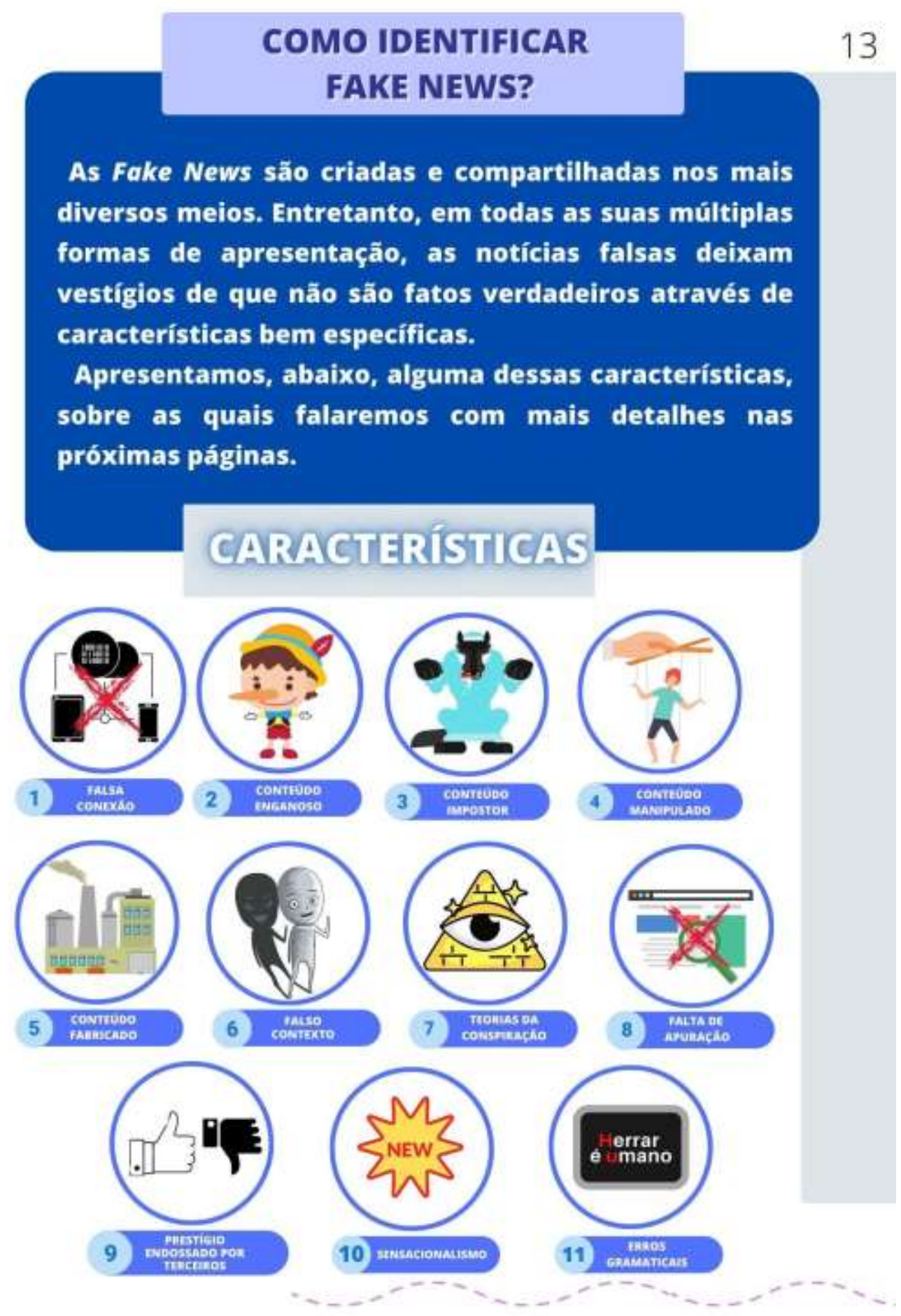

Fonte: Nascimento (2020)

São doze as categorias identificadas e agrupadas nesta página da cartilha, cuja identificação se dá também por imagens que ajudam o leitor a identificá-las de maneira mais lúdica. Na cartilha, propomos resumir cada uma delas, mas, por falta de espaço, exemplificamos uma delas: 
Figura 7 - Exemplo de apresentação da característica de Fake News política

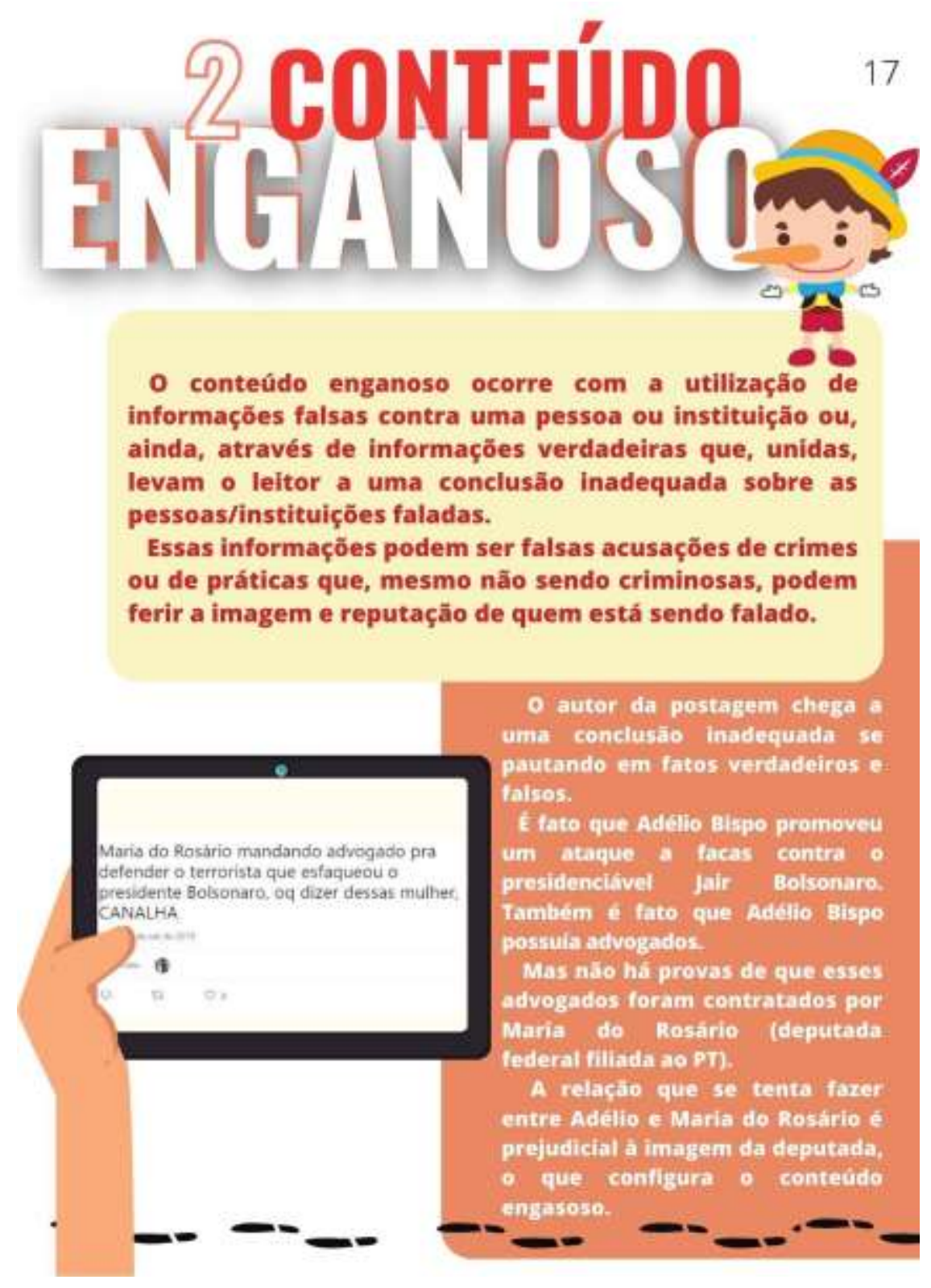

Fonte: Nascimento (2020)

Em conteúdo enganoso, categoria que emergiu dos dados da pesquisa para as fake news políticas, buscamos trazer a sua conceituação atrelada a uma exemplificação de um boato - evidentemente já desmistificado - que circulou em sites de redes sociais. Depois disso, partimos para mostrar se esses dados que aparecem se enquadram nas grandes categorias de expressão ou conteúdo, sempre buscando manter as mesmas cores nas páginas, para, de fato, dar a ideia para o aluno de continuidade do mesmo assunto, como se vê a seguir: 
Figura 8 - Exemplificação de categorias de conteúdo ou expressão na característica de Fake News política

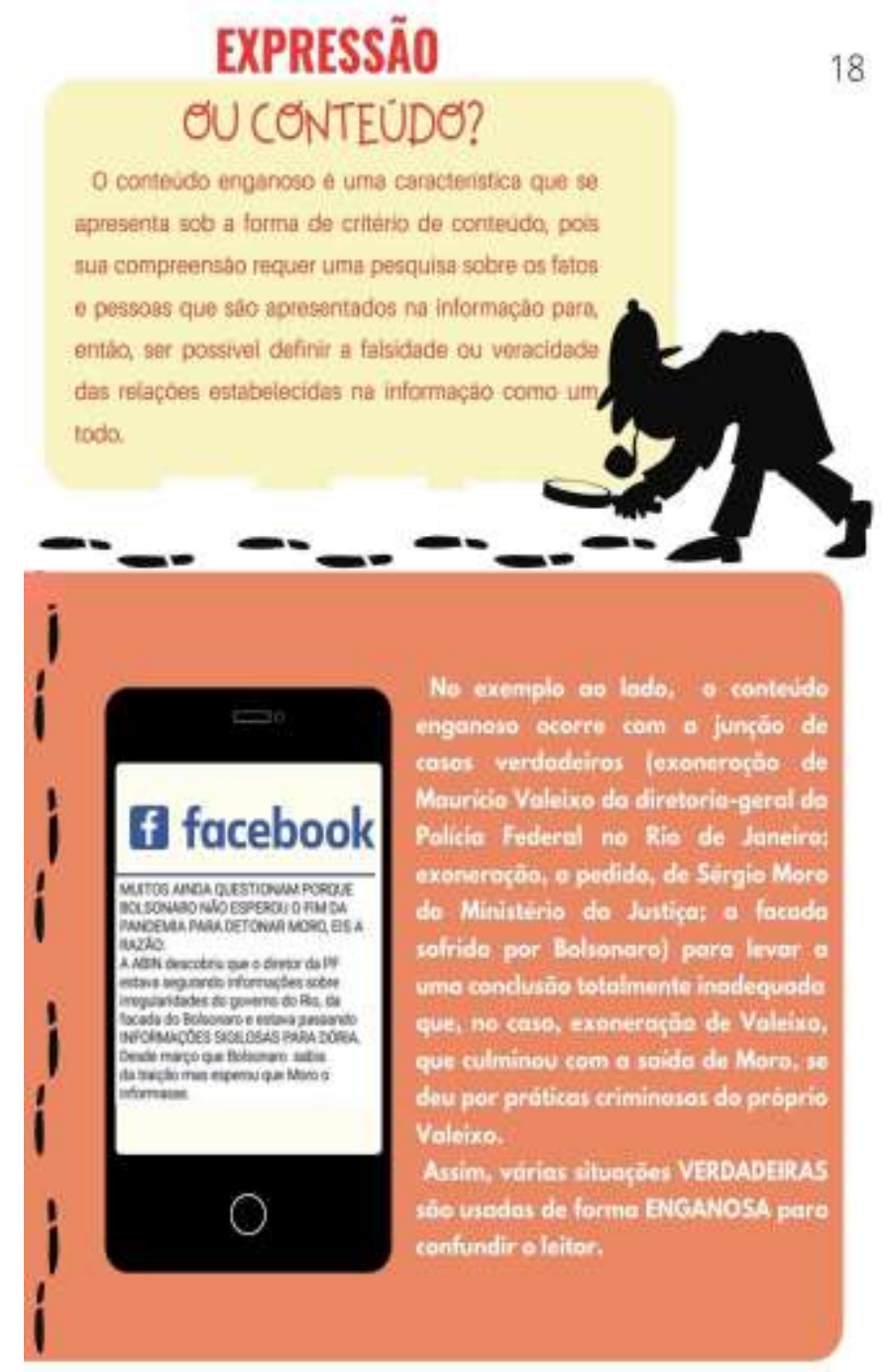

Fonte: Nascimento (2020)

A checagem realizada por Nascimento (2020), no que tange aos elementos de conteúdo, se deu com base na checagem de fatos ou fact checking, que se trata de um método criado no campo jornalístico através do qual há a verificação da informação visando avaliar se é, de fato, verdadeira ou falsa. Assim, foram seguidos, para fins deste artigo, os seguintes passos de verificação sugeridos por Nascimento (2020) na cartilha: 
Figura 9 - Exemplificação de categorias de conteúdo ou expressão na característica de Fake News política

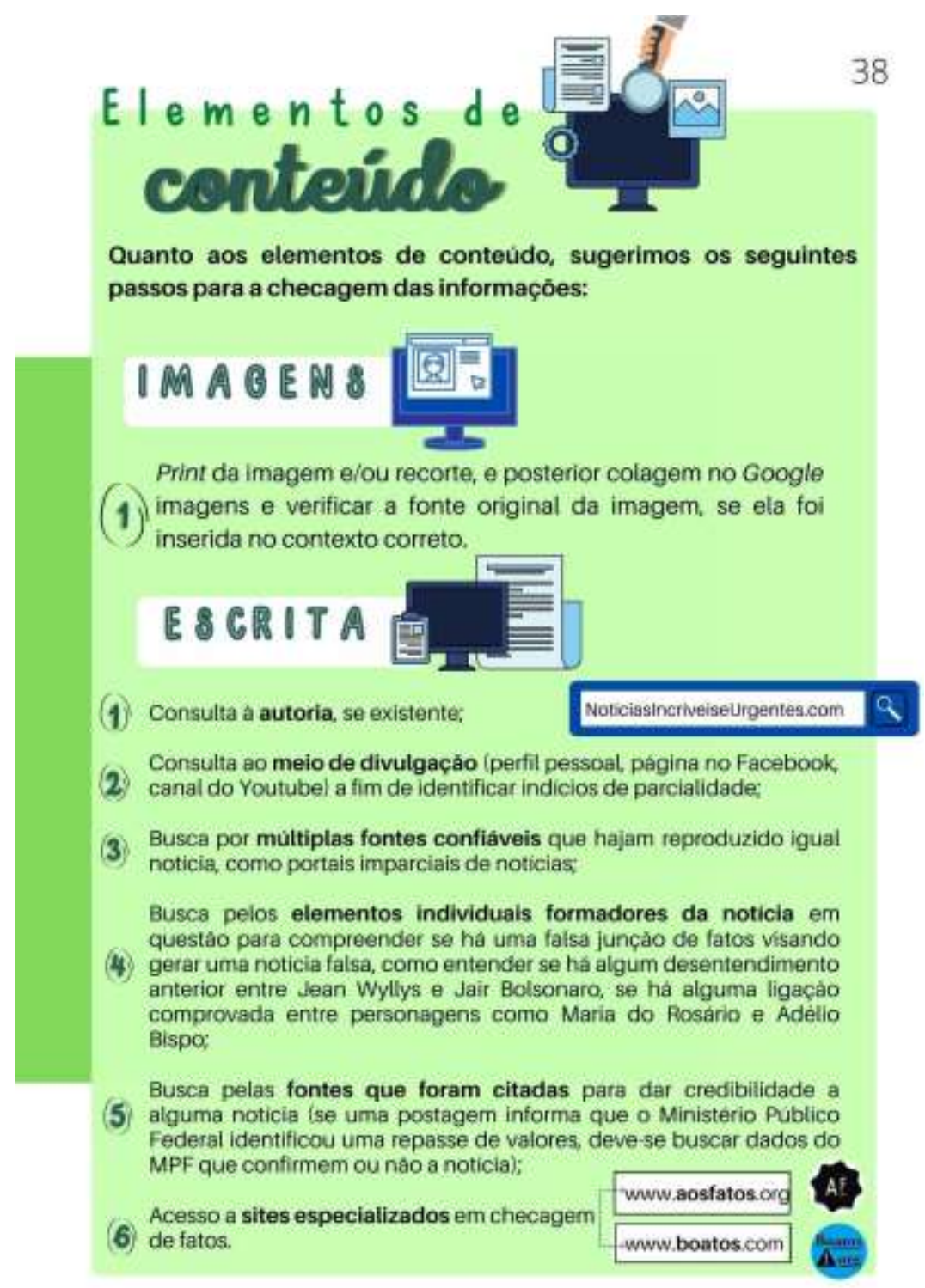

Fonte: Nascimento (2020)

Quanto aos elementos de expressão, embora sejam mais visuais, determinadas marcas nas Fake News podem ser pontuadas para que se torne mais fácil o entendimento e caracterização. Por fim, a checagem quanto aos elementos de expressão por nós empreendida neste artigo teve por base os pontos sugeridos por Nascimento (2020) os quais foram sugeridos na cartilha: 
Figura 10 - Como checar as informações?

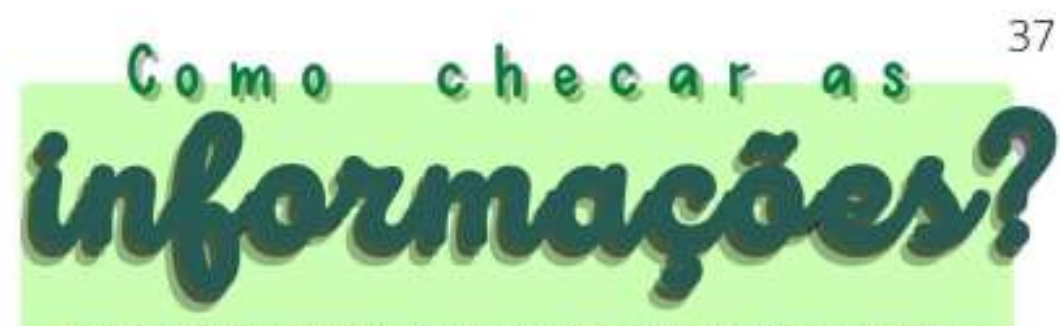

Depois de apresentarmos algumas das principais caracteristicas das fake news, assim como os modos como elas geralmente se apresentam (através da expressāo ou do conteúdo), vamos sugerir alguns modos de checagem das informaçōes que săo compartilhadas e chegam até nós.
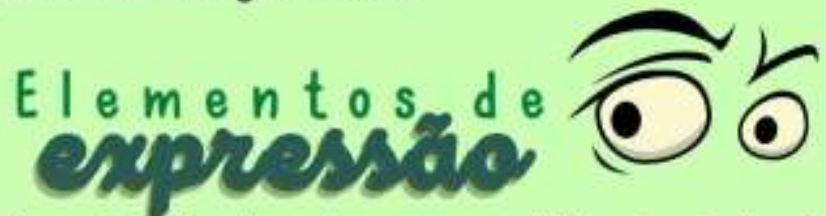

Os elementos visuais podem ser percebido através de alguns passos simples:

(1) Análise da imagem (se houver), se apresenta indicios de montagem ou se faz referencia, de fato, a quem diz fazer;

(2) Uso excessivo de pontuaçâo(!!!!!!), textos escritos em LETRAS MAIÚSCULAS, Uso de cores CHAMATIVAS

(3)

Chamadas que apontem uma descoberta algo que a midia esconde, algo completamente inovador ou URGENTE; Herrare unano

(4) Problemas gramaticais (erros ortograficos, de pontuaçaao, etc).

(5) Visualizar se ha fonte de onde as informaçoes foram retiradas.

Fonte: NoticiasincriveiseUrgentes.com

Fonte: Nascimento (2020)

Atente-se aqui que a ideia sempre foi trazer uma proposição de trabalho para salas de aula do Ensino Médio brasileiro, gerando, portanto, um material que esteja ao alcance tanto de professores quanto de alunos. Por questões de espaço, selecionamos apenas alguns trechos do produto, os quais se realizaram na análise de dados. 


\section{Considerações finais}

As fake news, embora sejam fenômenos bastante antigos, geram efeitos negativos até os dias atuais. Com o desenvolvimento das plataformas digitais, as notícias falsas se revestiram de novas roupagens e tiveram sua disseminação muito facilitada, sendo, em casos mais extremos, riscos a democracias de países ao redor do planeta.

Não obstante a roupagem que essas notícias falsas recebam com o passar dos anos, são lançados vestígios de sua falsidade. Tais vestígios, se percebidos pelo leitor, podem ser cruciais no processo de desenvolvimento crítico e quebra do processo de contaminação causado pelas fake news.

As características aqui apresentadas (a falsa conexão; o conteúdo enganoso; o conteúdo impostor; o conteúdo manipulado; o falso contexto; o conteúdo fabricado; o prestígio endossado por terceiros; o sensacionalismo; a falta de apuração e as teorias da conspiração) são apenas alguns dos muitos vestígios de falsidade que as fake news apresentam.

A identificação de tais características pode se dar tanto através de uma simples observação dos elementos que compõem a postagem (textos, imagens, legendas, áudios, vídeos), quanto através da checagem dos fatos através da busca externa por fontes confiáveis.

O trabalho de caracterização empreendido por Nascimento (2020) demonstra que a dinâmica das plataformas digitais não implica na mudança das características apresentadas pelas Fake News, conforme se comprovou através da análise de postagens realizadas em redes sociais diferentes.

Saliente-se que o rol de características proposto não tem a intenção de ser exaustivo. Trata-se, na realidade, de um rol editado após a análise de fake news políticas, de modo que a análise de outro tipo de notícia falsa pode implicar uma ampliação ou redução das características.

A cartilha apresentada é apenas um dos instrumentos que podem ser utilizados em sala de aula. A proposta, executada em torno das características localizadas nas Fake News e, por consequência, os procedimentos de checagem sugeridos, são apenas um dos muitos meios de se atuar na luta contra a disseminação de notícias falsas. Cabe a escolas e professores buscarem atuar com os instrumentos que mais se adequem às suas necessidades e realidades. 


\section{Referências}

A POLÍCIA Federal identificou *Aryane Campos* foi ela quem entregou a FACA para Adélio Bispo no crime contra Bolsonaro... [S. l.], 7 fev.2020. Twitter:@cathari74. Disponível em: https://twitter.com/Cathari74/status/122583 4776738828288. Acesso em: 30 abr. 2020.

ADVOGADO de defesa de Adélio Bispo, é também, advogado do molusco larápio de nove dedos. [...]. [S. l.], 15 nov. 2018. Facebook: Sandra Intervencionista. Disponível em: https://www.facebook.com/photo?fbid=202599664001283\&set=a.170865063841410. Acesso em: 6 dez. 2019.

ANGELIS, Carlos de. A ascensão da pós-verdade: ou como construir deuses na medida. Uno: D+I desenvolvendo ideias, Rio de Janeiro, mar. 2017. Disponível em: https:// www.revista-uno.com.br/numero-27/a-mentira-da-pos-verdade/. Acesso em: 12 abr. 2020.

BOYD, Danah. Did Media Literacy Backfire? [S. l.], 5 jan. 2017. Disponível em: https://points.datasociety.net/did-media-literacy-backfire-7418c084d88d. Acesso em: $1 \mathrm{abr}$. 2020.

BRANDINO, Géssica. Lula e Bolsonaro seguem à frente em disputa eleitoral, aponta pesquisa CNT. Folha de S. Paulo, São Paulo, 6 mar. 2018. Disponível em: https://www1. folha.uol.com.br/poder/2018/03/lula-e-bolsonaro-seguem-a-frente-em-disputa-eleitoralaponta-pesquisa-cnt.shtml. Acesso em: 1 abr. 2020.

BRASIL. Base Nacional Comum Curricular: Ensino Médio. Brasília, DF: MEC: SEB, 2017.

CHAPMAN, Martina. Fake news, echo chambers and filter bubbles: what you need to know. [S. l.], 29 jun. 2017. Disponível em: https://www.betterinternetforkids.eu/web/portal/ practice/awareness/detail?articleId=1990814. 2017. Acesso em: 30 mar. 2020.

COELHO, Jussara. Fake News e Pós-Verdade: várias formas de contar a mesma história. Comunica, Uberlândia, 6 jul. 2018. Disponível em: http://www.comunica.ufu.br/noticia/ 2018/07/fake-news-e-pos-verdade. Acesso em: 30 mar. 2020.

COPE, B.; KALANTZIS, M. (ed.). A pedagogy of multiliteracies: learning by design. New York: Palgrave MacMillan, 2015.

DAL MOLIN, Giorgio. Quem são os advogados que defendem o agressor de Bolsonaro?

D'ANCONA, Matthew. Pós-verdade: a nova guerra contra os fatos em tempos de Fake News. São Paulo: Faro Editorial, 2018.

Gazeta do Povo, Curitiba, 13 set. 2018. Disponível em: https://www.gazetadopovo.com.br/ politica/republica/eleicoes-2018/quem-sao-os-advogados-que-defendem-o-agressor-debolsonaro-14j3bpjbo08v0qg50fsxmwd8u/. Acesso em: 30 mar. 2020.

GIL, A. C. Métodos e técnicas de pesquisa social. 6. ed. São Paulo: Atlas, 2008.

HINE, C. Virtual Methods and the Sociology of Cyber-Social-Scientific Knowledge. Oxford: Berg, 2005.

MARQUES, Néstor F. Fake news de la antigua Roma. Titivillus Editor Digital. 2019.

NASCIMENTO, Isadora Oliveira do. Ensino de Língua Portuguesa por meio da análise de design e de elementos discursivos em fake news políticas: proposta de cartilha para identificação de notícias falsas. Dissertação (Mestrado em Ensino) - Universidade Federal Rural do Semi-árido, Programa de Pós-graduação em Ensino, Mossoró, 2020. 
OXFORD LANGUAGES. Word of the Year 2016. [S. l.], c2020. Disponível em: https://languages.oup.com/word-of-the-year/2016/. Acesso em: 9 abr. 2020.

PARISER, Eli. O filtro invisível: o que a internet está escondendo de você. Rio de Janeiro: Jorge Zahar, 2012.

PAULA, L. T.; SILVA, T. R. S.; BLANCO, Y. A. Pós-verdade e fontes de informação: um estudo sobre fake news. Revista Conhecimento em Ação, Rio de Janeiro, v. 3, n. 1, jan./jun. 2018. Disponível em: https://www.brapci.inf.br/v/a/30667. Acesso em: 15 abr. 2020.

RICHARDSON, R. J. Pesquisa Social: métodos e técnicas. 4. ed. rev. atual. e ampl. São Paulo: Atlas, 2017.

RODRIGUES, Auro de Jesus. Metodologia científica: completo e essencial para a vida universitária. [S. l.]: Avercamp, 2006.

SANTAELLA, Lucia. A Pós-Verdade é verdadeira ou falsa? Barueri: Estação das Letras e Cores, 2018. 98 p.

SERAPIÃO, F. Polícia Federal descarta participação de mulher em ataque a Jair Bolsonaro. Estadão, São Paulo, 10 set. 2018. Disponível em: https://politica.estadao.com.br/noticias/eleicoes,policia-federal-descarta-participacao-demulher-em-ataque-a-jair-bolsonaro,70002496125. Acesso em: 26 abr. 2020

SESERIG, Vincent Matheus; MÁXIMO, Maria Elisa. Mentira nos tempos de internet: a viralização de boatos nas redes sociais. In: ENCONTRO NACIONAL DE JOVENS PESQUISADORES EM JORNALISMO, 7., 2017, São Paulo. Anais [...]. São Paulo: ECA: USP, 2017. Disponível em: http://www.sbpjor.org.br/congresso/index.php/jpjor/JPJor 2017/paper/view/792. Acesso em: 16 dez. 2019

TOBIAS, Mirela Souza. O fenômeno da pós-verdade no facebook: análise das fake news relacionadas aos candidatos à presidência do Brasil no primeiro turno das eleições de 2018. 2018. Dissertação (Mestrado em Gestão de Unidades de Informação.) - Centro de Ciências Humanas e da Educação, Universidade do Estado de Santa Catarina, Florianópolis, 2018.

WARDLE, Claire; DERAKSHAN, Hossein. Information Disorder: Toward an Interdisciplinary Framework for Research and Policy Making. Brussels, Council of Europe, 2017.

Autores:

Isadora Oliveira do Nascimento

Técnica Administrativa em Educação Mestra em Ensino

Desinformação, Pós-Verdade, Pedagogia dos Multiletramentos, Criticidade isadora.nascimento@ufersa.edu.br

Vicente de Lima Neto UFERSA

Doutor em Linguística

Programa de Pós-graduação em Ensino Ensino de Línguas; Linguagem e Tecnologia vicente.neto@ufersa.edu.br 